\title{
GILGAMESJ.
}

\section{Een oud verhaal opnieuw verteld.}

Dat ik dit verhaal voor u opnieuw ga vertellen is niet alleen omdat het zoo oud is en zoo mooi-hoewel óók daarom!

Dit verhaal is zoo mooi, omdat het eenvoudig is en in zijn eenvoud reëel. "Realistisch" zult u misschien zeggen en u legt in dit woord iets disqualificeerends. Maar laten wij moderne menschen ons niet te gauw ergeren. Wij hebben eerst de realiteit der natuur omhuld met het kleed der beschaving en dan tillen we het weer op om onze verbeelding te prikkelen. Dat is de gecompliceerdheid van het leven van den modernen mensch. Maar de mensch der oulheid is niet gecompliceerd. Hij is eenvoudig, reëel. Zoo zijn ook de oude bijbelsche auteurs. En de auteur (als men tenminste van een auteur naar onze opvattingen kan spreken, in elk geval is hij onbekend) van dit verhaal is nog veel ouder dan $z i j$, haast duizend jaar ouder dan Mozes. 
Ook deze ouderdom van het Gilgamesj-epos is een aantrekkelijkheid. De groote Assyrische koning Assurbanipal (668-626 voor Chr.), "de groote en vermaarde Asnappar" uit Ezra 4: 10, wiens bibliotheek bij de opgravingen te voorschijn gekomen is, heeft ook dit epos laten overschrijven. Het was toen al een eeuwen oud geschrift, dat hij bij zijn verzameling voegde. Maar ook dit oude geschrift was reeds een bewerking van een nog ouderen vorm, den oud-babylonischen vorm. Daarachter liggen de Sumerische fragmenten, uit de vóor-semietische periode van het Babylonische land. Ook zijn fragmenten gevonden in andere talen bijv. het Hethietisch. Hieruit blijkt dat dit epos ook buitenlandsche bekendheid genoot.

Wat heeft hoofd en hart van deze menschen uit dien ouden tijd vervuld? Wat waren hun problemen? En wat hun oplossingen? Onze interesse hiervoor is wei de voornaamste reden, waarom ik dit verhaal navertel. In de ervaringen van Enkidoe en zijn vriendschap met Gilgamesj, waarvan we in de eerste helft van dit epos lezen zijn de gedachten, die men koesterde omtrent „beschaving” en „loutering” van den mensch, de onderwerpen waarrond de verhalen zich groepeeren. Als Enkidoe gestorven is en Gilgamesj onrustig geworden is door dit aanschouwen van den dood, gaat deze laatste op zoek naar het leven. Dit wordt verhaald in het tweede deel van dit verhaal. Daar lezen we dan hoe over het probleem van den dood wordt gedacht.

Het is niet mijn bedoeling commentaar en beschouwingen te leveren. Ook niet een wetenschappelijk-gefundeerde vertaling en reconstructie van dit niet in zijn geheel maar wel in talrijke inscripties overgeleverde verhaal te geven. Ik vertel slechts na. Soms voeg ik paraphraseerenderwijs een onmisbare verklaring in, soms ook bekort ik als het Oostersch verhaal naar ons gevoel te langzaam voortschrijdt. De lezer merke zelf $o p$, hoe in dit verhaal problemen belichaand zijn en hoe de menschen der oudheid op die problemen hun antwoorden hebben gevonden of ... niet gevonden! Ze hebben geen antwoord gevonden, ondat ze zochten met wel oude, maar toch menschelijke wijsheid. En waar ze antwoord gaven, daar hebben ze dat gegeven met dezelfde menschelijke wijsheid, zonder het licht der Openbaring van God. De Openbaring van God geeft licht over deze problemen van elk geslacht. Tegen den achtergrond van een verhaal als dit zullen we beter zien de uitnemendheid van onze antwoorden op deze ploblemen, een uitnemendheid, die niet voortvloeit uit wijsheid van ons zelf, maar uit de Openbaring van God.

$\mathrm{Na}$ deze inleidende opmerkingen volgt nu het verhaal. 


\section{GILGAMESJ IN OEROEK.}

Gilgamesj was een koning. Duizenden jaren is het geleden, dat hij regeerde, eeuwen vóér den tijd, waarvan een gedocumenteerde geschiedenis kan geschreven wordn. Hij was koning van Oeroek, een stad in het zuiden van het oude Babylonië. In den Bijbel heet deze stad Erech. Ze wordt daar genoemd naast Babel, Akkad en Kalne, oude steden, die de „beginselen” waren van het rijk van Nimrod, ,den geweldigen jager voor het aangezicht des HEEREN." In het tegenwoordige Warka, waar ook opgravingen zijn gedaan, liggen de ruines van het oude OeroekErech.

Lang, zooals alle koningen van dien grijzen voortijd, heeft Gilgames geregeerd: honderd en zesentwintig jaar! Hij was de zoon van een konings-dochter. Maar over zijn geboorte hangt een sluier. Priesters hebben zijn geboorte voorzegd. Zij zeiden tegen koning Enmekar van Oeroek: wanneer uw dochter een zoon baart, dan zal die zoon u uw koninkrijk ontrooven. Koning Enmekar was daarom op zijn hoede en sloot zijn dochter op in een burcht, waar hij haar zorgvuldig liet bewaken. Het baatte hem echter niet. De koningsdochter baarde in den burcht den zoon van een onbekende. Uit vrees voor den toorn van den koning wierpen de wachters het kind uit den toren. Dat zag een arend, de vogel met den scherpen blik. Hij schoot op het kind toe, ving het op op zijn vlerken vóordat het tegen de rotsen kon te pletter vallen. Behoedzaam bracht de arénd het kind naar een palmhof. Daar vond de hovenier het. Hij kreeg medelijden met dit kind, dat zeer schoon was. Hij voedde het op en noemde het Gilgamos. Toen Gilgamos groot geworden was stootte hij Enmekar van den troon. Zoo werd het priesterwoord vervuld.-')

Gilgamesj heeft alles doorvorscht tot aan het einde der wereld. Hij leerde zoo alle dingen kennen en doorgrondde de mysteries. Zoo heeft hij het verborgene kunnen openbaren, ja, de dingen van vóór den zondvloed heeft hij bekend gemaakt. Een verren tocht ondernam hij, moeite en inspanning doorstond hij. In een steen heeft hij zijn wedervaren gegrift.

Hij is de bouwer van den stadsmuur van Oeroek, de versterkte stad, en van den tempel van de godin der schoonheid en der liefde, de godin Isjtar, het „E-ANNA," het HEMELHUIS, den reinen tempel.

Een muur als koper zoo vast! Welk een bouwwerk! Zie toch die versterking! Niemand zou het zoo kunnen namaken! Voel dien hoek-

-') Dit geboorteverhaal is afkomstig uit Grieksche overlevering、(Aelianus). In de Babylonische verhalen is Gilgamesj' moeder een godin. De naam Gilgamos is de vergriekschte vorm van den naam Gilgamesj. 
steen, hoe hard hij is, sinde overoude tijden gelegd!

Kom nader en zie den tempel, waar Isjtar woont! Geen koning der toekomst zal ooit weer zulk een tempel kunnen bouwen!

Beklim Oeroeks muur! Loop er op! Bezie de fundamenten! Keur het metselwerk! Zijn het geen harde in het vuur gebakken steenen? Is die grondslag niet het werk der zeven wijzen?

De goden verleenden Gilgamesj een volkomen gestalte.

Voor twee derde deel is hij god, voor een derde deel mensch.

De zonnegod Sjamasj maakte hem schoon van gedaante.

De stormgod Hadad maakte hem groot van kracht.

Zijn lengte was elf el, de breedte van zijn borst was negen span.

Fier verhief hij zich.

Koning Gilgamesj was een tyran. Hij liet zijn onderdanen dienen. Zelf schreed hij met verheven tred als een woudos zoo sterk en in volle wapenrusting door de stad. Hij roept zijn mannen op en roert de trom. In hun huizen hooren de mannen van Ocrock hem en ze vreezen. Ze vreezen Gilgamesj, den tyran, den onstuimigc, den verwoede, zoowel bij dag als bij nacht. En hij is de machthebber in het sterke Oeroek. Hij is geweldig, sterk, heerlijk, verstandig. Hij laat geen zoon aan den vader, geen dochter aan haar moeder, geen vrouw aan haar man.

Daarom klaagden de mannen van Ocroek. De groote goden hoorden die jammerklachten. $Z$ ij riepen Aroeroe, de moedergodin, en zeiden tot haar: Gij hebt dezen man als een woudos, den machthebber van Oeroek, geschapen en zie, hij verdrukt zijn menschen. Maak hem nu ook een evenknie, een man, die zijn gelijke is en met wien hij zich k'an meten, opdat Oeroek rust krijge!

\section{ENKIDOE BIJ DE DIEREN.}

Aroeroe hoorde dit. $Z \mathrm{ij}$ dacht $z i c h$ een goddelijken evenknie van Gilgamesj. Zij wiesch haar handen, nam leem, vormde het en schiep Enkidoe.

Ook Enkidoe is een held, sterk; Ninoerta's kracht woont in hem. $\mathrm{Zijn}$ gansche lichaam is met haar begroeid. Zijn hoofdhaar is als dat van een vrouw, weelderig als graanhalmen. Hij heeft een pels als Soemoekan, de god der dieren. Hij vertoeft buiten de beschaving. Met de herten eet hij gras, met het gedierte des velds drinkt hij uit de bron en geniet hij de lessching van den dorst. $\mathrm{Hij}$ beschermt de dieren tegen gevaar dat hen bedreigt.

Dit verdriette Sangasus, den jager, die loerde op de dieren bij de bron. Drie dagen achtereen loerde hij zonder te kunnen vangen. Toen zag hij plotseling Enkidoe en ontstelde van schrik. Reeds weer thuis, 
zonder jachtbuit, was hij nog verstomd van schrik. Het hart joeg hem in de keel, zijn gelaat stond vertrokken van ontzetting, zijn lichaam trilde, hij leek wel een doode.

Hij wendde zich tot zijn vader en zei tot hem: vader, daar is een man gekomen uit de bergen. Hij is geweldig sterk, de sterkste van allen. Zijn kracht is vast als het hemelgewelf. Hij zwerft door de bergen en gaat drinken met het wild. Bij de bron stelt hij zich op als de vriend van de dieren. Ik ben bang voor hem, ik durf niet dicht bij hem komen. Maar hij stoort mij als ik aan het jagen ben. Graaf ik een valkuil-hij werpt hem weer dicht. Span ik een net--hij trekt het weer weg. Hij laat het wild, dat ik vangen wil, ontkomen.

De vader van den jager sprak tot zijn zoon: weet, mijn zoon, in Oeroek woont Gilgamesj. Ook hij is sterk als niemand. Zijn kracht is vast als het hemelgewelf. Ga daarom naar Oeroek, naar Gilgamesj en deel hem mee, wat Enkidoe doet.

De jager volgde den raad van zijn vader op en ging naar Oeroek en vertelde Gilgamesj van Enkidoe.

Gilgamesj zeide tot den jager: ga terug naar uw jachtveld en neem een Ischtar-deerne mee. Als Enkidoe bij de bron komt om met de dieren te drinken, dan moet zij haar kleederen uittrekken en hem haar bekoorlijkheid toonen. Wanneer hij haar dan ziet, zal hij naar háár toegaan en de dieren, waarmede hij nu in de steppe leeft, zullen van hem vervreemd raken.

Toen ging de jager terug naar de steppe. Met zich mee nam hij een deerne, een gewijde aan Isjtar, de godin der schoonheid en liefde, opdat de natuurmensch door zijn omgang met haar zou ontwaken uit zijn naiven natuurdroom.

Na drie dagen kwamen zij bij de bron en wachtten daar twee dagen lang. Toen kwamen de dieren drinken. Ook Enkidoe kwam om niet de dieren te genieten le lessching van den dorst.

Toen zei de jager tot de deerne: zie, daar is hij! Werp af nu uw kleederen! Toon hem uw bekoorlijkheid! Hij zal bij u komen, schrik voor zijn liefkozing niet terug. Laat hem zich neervlijen op uw gewaad. Doe hem, den woeste, het vrouwelijke smaken. Terwijl hij u mint, zal het wild in de steppe van hem vervreemden.

De deerne deed zooals de jager zeide. Enkidoe kwam naar haar toe. Zij lict zich omhelzen. En Enkidoe genoot het vrouwelijke zeven dagen en zeven nachten.

Toen hij zich aan haar verzadigd had, wilde hij terugkeeren naar zijn dieren. Daar bemerkte hij welke verandering er met hem had plaats gegrepen! Want de herten gingen nu voor hem op de vlucht. Hij stak 
de hand naar hen uit, maar de dieren der steppe ontweken hem. Vol ontzetting merkte Enkidoe dit op. Hij stond als versteend, zijn knieën knikten. Hij had verloren wat hij bezat: zijn dieren ontvluchtten hem!

Maar hij was ontwaakt en tot inzicht gekomen.

Hij keerde terug naar de deerne en zette zich bij haar neder. Hij keek haar aandachtig aan en luisterde gespannen naar haar woorden. Zij zeide tot hem: Enkidoe, gij zijt nu ontwaakt, gij hebt inzicht verkregen. Gij zijt nu als een god. Wat zwerft ge hier nu rond in de steppe bij de dieren? Ga mee naar Oeroek, naar de versterkte stad, naar den tempel, waar Anoe en Isjtar wonen. Daar is ook Gilgamesj! Sterk is hij als een woudos, onoverwinnelijk. Niemand is zoo sterk als hij!

Hij hoorde haar woorden met instemming aan. Hij was nu tot inzicht gekomen en begeerde een hem gelijke. Daarom zeide hij tot de deerne: Kom, neem mij mee naar Oeroek, naar den tempel van Anoe en Isjtar, naar Gilgamesj. Ik zal hem, den sterke, den woudos, uitdagen met luider stem. Ik zal tot den onoverwinnelijke roepen: ik ben de sterkste! Ik zal de lotsbestemming veranderen! $\mathrm{lk}$, de man der natuur, ben geweldig in kracht.

Toen zeide de deerne tot hem: laat ons gaan; maak u gereed. Ik weet, waar Gilgamesj is. Ik zal hem u toonen. Kom mee naar Oeroek, Enkidoe, naar de versterkte stad. Daar wonen de menschen, prachtig gekleed. Daar is het feest, alle dagen en alle nachten. Daar maken knapen vreugde met vele schoone deernen die in weelderigheid verlokken de edelen van Oerok. Daar toon ik u Gilgamsj.

Gij zijt vol overmoed, maar weet, hij is een geweldige. Hij schept behagen in anderer gejammer. Gij zult hem zien. Schoon en forsch is zijn mannelijke gestalte, prachtig van leden is hij. Hij is sterk, sterker dan gij. Dag en nacht roert hij zich. O Enkidoe betoom toch uw woede tegen hem. Bedenk, hij is de lieveling van Sjamasj, den zonnegod. Die drie groote goden, Anoe, Enlil en Ea, de god van den hemel en de god van de aarde en de god van de diepte hebben hem kennis verschaft. Hij weet al van $u$ ! Voordat gij van het gebergte kwaamt, heeft hij $u$ in Oeroek al gezien in zijn droomen.

\section{DE ONTMOETING VAN GILGAMESJ EN ENKIDOE.}

Gilgamesj had gedroomd en hij vertelde zijn droomen aan zijn moeder. „Moeder" zoo zegt hij, „vannacht in mijn droom liep ik met krachtigen tred tusschen de mannen der stad. Opeens waren alle sterren des hemels rondom mij. Daar viel iets geweldigs op mij! Het was als het hemelgewelf van Anoe! Ik wilde het optillen, maar het was mij te zwaar. Ik wilde het bewegen, maar kon niet. Al de mannen van Oeroek en van het geheele land kwamen er bij staan. En zij kusten het uit 


\section{1.}

eerbetoon de voeten. Toen spande ik mij in, ook hielpen mij de mannen; ik beurde het op! Zie, hier breng ik het bij u."

De droom, hét openbaringsmiddel uit de oudheid, ook in vele bijbelsche verhalen, kan verklaard worden door zijn moeder, de godin Ninsu, de alwetende. Zij zegt tot Gilmasj:

„Deze droom gewaagt van uw evenknie. Hij is in de steppe geboren en zwierf door de bergen. Als ge hem ziet zult ge blij zijn. De mannen kussen zijn voeten uit eerbetoon. Gij zult hem liefhebben met de liefde voor een vrouw. Gij zult hem tot uw vriend maken en hem hier bij mij brengen. Hij is Enkidoe en wordt uw vriend in nood."

Daarna droomde Gilgamesj weer en vertelde ook dezen droom aan zijn moeder.

„Moeder zoo zegt hij, ,ik zag weer een droom. Alles was erg verward. Op de straat in de vesting Oeroek lag een bijl. Menschen stonden er om heen en drongen op. De bijl leek vreemd, toch was ik blij toen ik ze zag. Ik kreeg ze lief met die liefde voor een vrouw. Ik greep den bijl aan en ging er naast liggen."

Ninsu, wie alles weet, zeide tot haar zoon: „dat gij u naast de bijl hebt neergelegd, beduidt, dat zij an u gelijk is. Het is weer Enkidoe, uw vriend in nood. Hij is sterk, zijn kracht is vast als Anoe's hemelgewelf.

Gilgamesj antwoordde: „Moge ik dezen vriend verkrijgen! Een groot geschenk zal hij voor mij zijn!"

Gilgamesj peinsde over zijn droomen, Enkidoe zat bij de deerne. Hij had naar haar woorden geluisterd. Hij zou nu niet langer met de dieren zwerven over bergen en door steppen.

De deerne zeide tot hem:: sta op, Enkidoe, ik breng u naar den tempel van Anoe, naar E-ENNA. Daar is de held Gilgamesj. Gij zult hem liefhebben met een liefde als voor vrouwen. Gij zult hem liefhebben als u zelf. Lig niet langer op den vochtigen grond!

Enkidoe luisterde naar haar raad. Hij deed zijn vacht uit. Andere kleederen trok zij hem aan, kleederen der menschen. Toen kleedde zij zich zelf. Ze greep hem bij de hand en leidde hem als een moeder. Eerst bracht ze hem naar de herders bij de schaapskooien.

De herders kwamen bijeen en noodigden den gast aan hun maaltijd. Maar Enkidoe placht met de herten het kruid van de steppe te eten, te drinken de melk van de hertereeën. Nu kreeg hij de spijze der menschen! Verlegen keek Enkidoe rond, want brood eten en bier drinken, dat kende hij niet.

Toen zeide de deerne tot hem: „eet toch van het brood, het voedsel der menschen; drink toch van het bier, zooals de menschen gewoon zijn." 
Toen at Enkidoe van het brood tot hij verzadigd was en van het bier dronk hij zeven kruiken.

Zijn beschroomdheid week van hem. Hij gevoelde zich als bevrijd. Zijn innerlijke vreugde stond op zijn gelaat te lezen. Hij reinigde zijn harig lichaam. Hij zalfde zicht met olie. Hij kleedde zich met kleederen der menschen. Hij at de spijzen der menschen. Hij was nu een man!

Hij neemt een zwaard en waakt bij de kudde, des nachts als de herders slapen.' De dieren, zijn vroegere vrienden, bestrijdt hij. Hij grijpt de wolven, hij vangt de leeuwen. De herders kunnen 's nachts slapen, want Enkidoe, de sterke, waakt, alleen.

Als hij zijn oogen opslaat ziet hij een man naderen. Het is een afgezant van koning Gilgamesj. Wat komt hij hicr doen, zoo vralagt Enkidoe aan de deerne, vraag hem. ik wil hooren, wat hij zegt. De deerne roept den man aan en vraagt hem: „waarheen gaat uw moeizame tocht?" De man antwoordt Enkidoe: „Gilgamesj noodigt $u$ tot de vergadering der mannen. Hij hecft een maaltijd gereed voor heel de stad. Begroet den koning van Oeroek, den held. Vertoon u aan Gilgamesj, den geweldige den tyran. Hij onteert elke bruid en laat ze eerst daarna den man. Door het besluit der goden staan voor hem de bruidsvertrekken open. Dat is het voorrecht van dezen geweldenaar.

Toen Enkidoe dit hoorde werd hij bleek van woede, hij, die het zwakke verdedigde, het wild tegen den jager, de kudde tegen de roofdieren. Hij zal de maagden verdedigen tegen den tyran.

Hij riep uit: „lk zal den sterke, den woudos uitdagen, met luider stem. Ik zal tot den onoverwinneliike roepen; lk ben de sterkste. Ik zal de lotsbestemming veranderen. Ik, de man der natuur, ben geweldig in kracht.

Met deze woorden ging Enkidoc naar Oeroek en de deerne volgde hem.

Toen hij Oeroek binnenkwam schaarden alle mannen der stad zich om hem heen. De menschen zagen hem staan op de straat en zeiden „Hij is als Gilgamesj! Hij is niet zóó groot, maar zijn beenderen zijn sterker. Hij is een kind uit de bergen en dronk reeënmelk.

$\mathrm{N}_{\mathrm{u}}$ zullen de wapens kletteren in Ocroek--zoo hoopten de mannen der stad: want hier is een sterke, die den tyran, den geweldenaar zal keeren; hier is Gilgamesj' evenknie. Een man als cen god, die Gilgamesj weerstaan zal, vannacht, als hij naar Isj-chara, de bruid, gaat om haar te bezitten, vóór den echtgenoot. Enkidoe zal hem de toegang versperren!

Daar nadert Gilgamesj .... .

Enkidoe zet den voet voor de deur van de bruidskamer om Gilgamesj de toegang te beletten. 
Toen grepen ze elkaar aan ...

Ze standen, gebogen, de spieren gespannen, in evenwicht van krachten. De deurpost brak onder hun druk, de muur schudde.

Lang duurde de strijd. Als stieren stonden ze, de een hield den ander in bedwang.

Met vernieuwde inspanning zette Gilgamesj zich af tegen den grond, de knieën gebogen ....

Toen bezon hij zich.

Zijn woede bedaarde.

Hij liet Enkidoe los en bood hem zijn vriendschap aan.

Toen zeide Enkidoe tot Gilgamesj: als een eenige onder de mannen heeft uw moeder u gebaard: $O$, zoon van Ninsu, de goddelijke wilde koe uit de vesting Oeroek. Gij overtreft alle mannen. Enlil heeft het koninkrijk over de menschen voor u bestemd!

Toen kusten ze elkander als vrienden.

Daarna bracht Gilgamesj zijn vriend bij zijn moeder en, vol lof over hem, spreekt hij opgetogen:

„De sterkste in het land is hij!

Kracht heeft hij als de burcht van den hemelgod Anoe!

Nieman kan tegen hem stand houden.

Neem hem, mijn vriend genadig aan."

Als zij Enkidoe's verschijning vreemd vindt, gaat Gilgamesj verklarend voort:

Enkidoe heeft vader noch moeder.

Zijn golvende haardos werd nimmer gekort.

Hij is in de steppe geboren en niemand voedde hem op.

\section{DE TOCHT VAN DEN VRIENDEN NAAR CHUMBABA.}

In Oeroek doet Enkidoe met Gilgamesj en de mannen der stad mee aan het wulpsche leven. Doch dit verzwakte den sterken natuurmensch. Hij gevoelt zich uitgeput. Gilgamesj ziet het aan hem en als de vrienden samen zijn zucht Enkidoe. Hij, de sterke, krijgt tranen in de oogen. Vol medelijden over de ellende van zijn vriend neemt Gilgamesj zijn hand in de zijne en vraagt wat hem deert. Hij is moede, zoo zegt hij, van het leven in de stad. Dan oppert Gilgamesj het plan samen de stad te verlaten. „Laat ons samen avonturen beleven!" Ver in het Westen is het cederwoud van Chumbaba, den reus. Zijn woud is vol kronkelpaden. Het gelijkt op het doodenrijk. Daarheen wil Gilgamesj met Enkidoe gaan om den reus te dooden. Maar Enkidoe weet beter dan Gilgamesj, wat dit beteekent en werpt hem tegen: :

Toen ik met het wild op de bergen doolde heb ik het woud gezien. Mijlen ver strekt het zich uit. Wie zal daarin doordringen? Chumbaba 
brult als een watervloed. Uit zijn mond komit vuur. Zijn aanval is doodelijk. Waarom wilt ge dit ondernemen? De strijd met Chumbaba is ondoenlijk!

Gilgamesj laat zich echter niet van zijn plan afbrengen. Overmoedig zegt hij toch te zullen gaan:

Ik wil den cederberg daar midden in het woud beklimmen.

Mijn bijl is mijn helper!

En gaat ge niet mede, dan ga ik alleen.

Maar Enkidoe blijft bezwaar maken:

Chumbaba, de bewaker van het cederwoud, is een krijgsman, sterk en altijd waakzaam. God Enlil heeft hem aangesteld als een verschrikking voor ieder die nadert. Wie in dat woud doordringt kont om!

Dan zegt Gilgamesj:

Sterven moeten we toch, wij aarde-menschen!

Eeuwig het zonlicht genieten-dat doen slechts de goden!

Onze dagen zijn afgemeten.

IJdel is ons werk.

Maar gij zijt bang voor den dood!

Waar is uw heldenmoed?

Ik zal vooropgaan en gij mij bemoedigen!

En val ik-welaan, dan blijft mijn naam en men zal zeggren:

Gilgamesj, hij viel in den strijd tegen Chumbaba, den reus.

Geprikkeld door deze woorden geeft Enkidoe toe. De lichte spot met zijn bezorgdheid heeft hij pijnlik gevoeld. Maar hij zal voor Gilgamesj niet onderdoen. Hij wil ook roem verwerven en zegt: Aanvaard zonder vreezen den tocht. Ik weet, waar Chumbaba woont. Geef bevel tot vertrek!

Samen gingen ze naar de smeden, gaven opdracht wapens te maken, bijlen en zwaarden, zwaar van gewicht met gouden gevesten.

Gilgamesj roept de oudsten bijeen. Vol vreugde komen de burgers in Oeroeks poort met zeven grendels. Daar spreekt Gilgamesj:

Ik zal gaan naar Chumbaba den reus. Ik, Gilgamesj, wil zien, wat bij geruchte bekend is. Vellen $\mathbf{z} \mathbf{g}$ ik in het cederwoud Chumbaba, wiens roem de landen vervult. Ik zal toonen, hoe sterk de zoon van Oeroek is. Den ceder houw ik om, een eeuwigen naam wil ik mij haken!

Toen spraken de oudsten als Enkidoe en zeiden:

Uw jeugdig hart is overmoedig, Gilgamesj! Wie zal doordringen in Chumbaba's woud? Chumbaba brult als een watervloed. Uit zijn mond komt vuur. Zijn aanval is doodelijk. Waarom wilt gij dit ondernemen? De strijd met Chumbaba is ondoenlijk!

Lachend ziet Gilgamesj zijn vriend aan. Zijn plan is onwrikbaar. 
Dan raden de oudsten hem toch eerst het orakel van Sjamasj den zonnegod te raadplegen.

Knielend heft Gilgamesj de handen omhoog tot gebed:

Sjamasj, ik ga, tot $u$ hef $i k$ de handen op.

Behoed mij en laat mij in vrede tot de stad terugkeeren.

Wees mijn beschermer.

Daar de vooorteekens ongunstig blijken klampt Gilgamesj zich vaster aan zijn vriend: wanneer ik behouden terugkeer van dezen onbekenden wegr, zal ik in liefde voor $u$ mij wijden aan $u$ en uw geluk; zal ik $u$ een troon tot zetel geven!

De dienaren brachten de wapens, de helden togen ze aan.

De mannen der stad omringden hen: :wanneer keert ge terug?

De oudsten spraken wenschen uit en gaven goeden raad:

Gilgamesj, vertrouw niet op uw eigen kracht.

Anders luisteren wij naar $u$, o koning!

$\mathrm{Nu}$ moet gij luisteren naar ons!

Laat Enkidoe vooropgaan.

Wie voorgaat past op den makker.

Hij kent den weg, de paden door het woud.

Hij kieze het pad, wees gij voorzichtig.

Sjamasj doe $u$ uw doel bereiken.

Hij effene u den moeilijken weg.

Hij leide uw voet op den berg.

Brenge de nacht $u$ gunstige droomen.

Helpe u Lugalbanda, de god van Oeroeks vorsten.

Geve de overwinning u kinderlijke vreugde.

Baad uw voeten in Chumbaba's bloed.

Graaf elken avond naar water opdat ge steeds frisch water voor Sjamasj kunt plengen.

Gedenk Lugalbanda, den god van Oeroeks vorsten.

Toen antwoordde Gilgamesj de oudsten en zeide:

Met Enkidoe ga ik, uw raad neem ik aan.

Daarop gaan de vrienden naar Gilgamesj' moeder, naar Nin-sun, de groote koningin. $\mathrm{Zij}$ is verstandig en weet alle dingen. Tot haar zegt Gilgamesj: Hoor moeder, belangrijk bericht: Wij ondernemen een verren tocht, naar Choembaba, we wagen een strijd, nog nimmer gevoerd en betreden een onbekenden weg. Bid toch tot Sjamasj en vraag hem over onze terugkeer, over den uitslag van onzen strijd, over ons streven alles uit te delgen uit het land, wat Sjamasj mishaagt.

Met een bezorgd hart luistert Nin-sun naar haar zoon. Zij trekt zich terug in haar vertrek en tooit zich met passende gewaden en siera- 
den. Gegord en met de diadeem op plengt zij schalen waters. Ze klimt op het dak van haar paleis en offert wierook voor Sjamasj, den grooten god. Met opgeheven handen slaakt zij de verzuchting:

Waarom, Sjamasj, hebt gij mij Gilgamesj tot zoon gegeven?

Waarom hebt gij hem een hart vol onrust bereid?

$\mathrm{Nu}$ hebt gij hem weer aangespoord naar Chumbaba te trekken, langs onbekende wegen en te wagen een strijd, nog nimmer gevoerd.

Wanneer gij neerziet op zijn pad, wees dan gedachtig aan zijn terugkeer en dat hij het cederwoud behouden bereike, den reus mag slaan en verdelgen uit het land, al wat u mishaagt. Dat ook Aja uw gemalin $u$ hem indachtig make. En des nachts-dat dan de sterren en Sin, de maangod, uw vader, hem bewaken!

Met reukwerk deed zij haar bede vergezeld gaan.

Toen ontbood zij Enkidoe en zeide tot hem:

Enkidoe, held, niet zijt ge een kind van mijn schoot. Gilgamesj deed $u$ genieten het leven met priesteressen en godegewijden. Nu neem ik u aan als mijn zoon.

Een kleinood legde ze om zijn hals.

De vrienden zijn op reis gegaan. Weinig hielden ze rust. Des avonds groeven ze water om aan Sjamasj te plengen. Na drie dagen hadden ze een afstand van zes weken afgelegd. Toen stonden ze voor den ingang van het cederwoud, waar Choembaba's geweldige wachter waakte. Gilgamesj aarzelt. Maar Enkidoe herinnert hem aan zijn overmoedige woorden. „Houd nu stand, gij zoon, in Oeroek geboren.” Hij ziet ook, dat de wachter, die zeven harnassen droeg, er maar een aan had; de andere zes lagen op de grond.

Gilgamesj stormt nu op den wachter los. Die vlucht en roept om Choembaba.

De ingang tot het woud is nu vrij. Toch is Enkidoe bevreesd er in te gaan. Hij gevoelt zich zwak. Maar Gilgamesj bemoedigt hem: „We zijn toch alle bergen overgekomen? Het doel ligt nu voor ons! Ge zijt toch ervaren en sterk in den strijd? Wedijver met mij in moed, dan wijkt uw zwakheid van $u$ ! Zoudt gij hier blijven? Samen gaan we voort! Vergeet den dood! Vrees niets! Wie valt in den strijd verkrijgt roem!

Ze trokken verder en kwamen diep in het woud. Daar standen ze verwonderd over de hoogte der ceders. Wegen waren aangelegd, paden kruisten elkaar. Een voetspoor wees, waar Choembaba was gegaan. Ze zagen den cederberg, de woonplaats der goden. Daar zetelde Irnini, de oorlogsgodin. Voor den berg spreidden de ceders hun takken breed uit en boden verkwikkende schaduw. Chumbaba zagen zij niet. 
Dien nacht droomde Gilgamesj, dat zij boven op den berg stonden en de berg instortte. Enkidoe verklaart den droom gunstig: de berg is Choembaba! Wij zullen hem grijpen en dooden en zijn lijk wegwerpen in het veld! Den volgenden nacht droomt Gilgamesj weer: de berg stortte in en wierp mij ter aarde, greep mijn voeten en liet ze niet weer Ios. Een verblindend licht straalde. Daar verscheen mij een man. Hij was van grooote schoonheid, hij was de schoonste uit het land. Hij trok mij onder den berg vandaan, zoodat ik weer op mijn voeten stond. Hij verkwikte mij met water. Weer verklaart Enkidoe den onheilspellenden droom gunstig.

Gilgamesj vraagt een derden droom, met voorteeken voor Enkidoe.

De derde droom komt. Vol ontzetting wekt Gilgamesj zijn vriend om den huiveringwekkenden droom te vertellen: de aarde dreunde van donderslagen, de hemel schreeuwde, bliksem flitste, een vuur laaide op, het regende dood en verderf, overal viel asch.

Enkidoe verklaart ook dezen vreeselijken droom gunstig.

De vrienden gaan een ceder vellen.

Op het gekraak komt Choembaba woedend toegesneld: wie beschadigt mijn boomen, de troetelkinderen van mijn bergen?

Tegelijk met Choembaba verschijnt ook de hemelgod Sjamasj. Hij - roept de helden bemoedigend toe: komaan vreest niet!

Tegen Choembaba verheffen zich acht stormwinden. Die slaan hem de oogen dicht. Hij kan vooruit noch achteruit. Hij gaf zich gewonnen en smeekte om zijn leven: Gilgamesj, gij zijt mijn heer, ik uw knecht. lk zal voor u vellen de boomen gekweekt op mijn bergen. Ik bouw u daarvan huizen. Maar Enkidoe zeide: bewillig niet, laat Choembaba niet leven! Toen hieuwen zij hem het hoofd af.

\section{DE VERLEIDING VAN ISJTAR.}

Als overwinnaars keeren de vrienden naar Oeroek terug.

Gilgamesj maakt zich gereed voor een overwinningsfeest. Hij doet zijn vuile kleederen uit en wascht zich van het vuil van den tocht. Schoone kleederen trok hij aan. Zijn haardos hangt hem zwierig op den rug. Zijn wapens blinken weer en op zijn hoofd prijkt de diadeem.

Daar valt op hem de blik van Isjtar, de godin in wier tempel Enkidoe zich ziek heeft gedronken aan de wellust met godegewijden. Begeerig ziet de godin de schoone gestalte van den held en zegt tot hem: „Kom, Gilgamesj, wees mijn! Geef mij uw vrucht. Wees mijn man en ik uw gade. Ik laat voor $u$ inspannen de wagen belegd met goud en edelgesteenten, de wagen met wielen van goud, getrokken door groote muildieren. Kom in mijn huis, held van det cederwoud, waar cedertakken geuren. Eere zult ge verkrijgen. Priesters zullen uw voeten kussen, 
vorsten zullen voor $u$ knielen. Rijkdom zal u geworden. De opbrengst van landen en bergen zal $u$ als cijns gebracht worden. Uw kudden zullen tweelingen, ja drielingen werpen. Uw lastdieren zullen sterk zijn, uw paarden vurig, zooals niemand anders ze heeft.

Gilgamesj laat zich door deze verlokkende woorden niet verleiden. Dat is zijn zedelijke kracht, die hij door de louteringn van den strijd heeft verkregen. Maar zijn antwoord aan de godin is hoonend:

Wat moet ik u geven als ik u tot gade neem?

Zijt ge tevreden met zalf en gewaden en brood?

Spijs moet ik u geven den goden waardig en majesteitelijke kleeding.

Waarom zou ik u als gade nemen?

Ga bij den weg zitten, den mantel om, dan kan u nemen, wie will

Gij zijt als een oven, dic geen warmite geeft, een deur, die niet sluit, maar tocht,

een paleis, dat den held bedrukt maakt,

een siergesp, die den sluiter vernielt,

pek, dat besmet, wie het aanraakt,

een waterzak, die zijn drager nat maakt,

kalk, waarvan de muur scheurt,

een edelsteen, die den vijand toeschittert,

een schoen, die den voet beknelt.

Wien van uw vrienden hebt ge getrouw bemind?

Welke herdersknaap kon u langdurig behagen?

Ik ken uw geliefden, zes zal ik er noemen,

ge hebt ze laten verongelukken, in dieren veranderd

en plaagt hen voortdurend.

Daar is Tammoez, uw jeugdminnaar-')

jaarlijks moet hij beweend worden.

Daar is de herdersknaap, die ge in een gaai veranderd hebt.

Toen hebt ge zijn vleugel stukgeslagen.

Nu roept hij in de bosschen: kappi, kappi! ")

Daar is de leeuw, de sterke ....

kuilen hebt ge voor hem gegraven, zeven en nog eens zeven.

Daar is het paard, dapper in den strijd.

Zweep en sporen hebt ge het toebedeeld

en mijlen, om in zweet af te leggen.

Troebel water kan hij drinken.

Zijn moeder Silili bezorgt ge verdriet.

') Zie Ezech. 8: 14.

") =mijn vleugel". 
Daar is de veehoeder, dien ge hebt liefgehad.

Hij stookte uw vuur en bakte uw koeken,

hij slachtte uw bokjes.

Gij hebt hem geslagen en in een wolf veranderd.

$\mathrm{Nu}$ verjagen de andere veehoeders hem

en de honden bijten hem in de beenen.

Ge hebt Isjoellanoe bemind, uws vaders tuinman.

Hij bracht u dagelijks dadels,

liet van alles prijken op uw disch.

Uw oog heeft hem begeerd.

Ge zijt naar hem toegegaan met de woorden:

Mijn Isjoellanoe, prachtig, sterk zijt gij!

Laat ons samen genieten, betast mijn dijen!

Maar hij was verstandig.

$\mathrm{Hij}$ begeerde niet wat het zijne niet was.

„wat verlangt ge van mij", zei hij.

„Wat mijn moeder niet bakte, heb ik niet gegeten!

Zal ik dan nu eten het brood der verleiding,

dat stinkt en vuil is?"

Toen ge dit hoordet hebt ge hem geslagen,

een mol van hem gemaakt.

Nu wroet hij in het donker der aarde.

Mijn liefde met u zou ook mij, den zevende, in het ongeluk storten.

Woedend steeg Isjtar op naar den hemel, naar Anoe haar vader en Antoe, haar moeder om zich te beklagen over de beleedigingen van Gilgamesj. Maar Anoe zeide: dat zal je eigen schuld wel zijn. Zonder hierop in te gaan vraagt Isjtar: geef mij den hemelstier en laat die Gilgamasj dooden. En geeft ge hem niet, dan sla ik de deur van de onderwereld stuk en laat ik de dooden los om de levenden te verdelgen. Zij die dood zijn, zijn meer dan die leven! Toen zeide Anoe: als de hemelstier neerdaalt komt er honger, zeven jaren. Hebt ge voor zeven jaar koren in voorraad en gras voor het vee voor zeven jaren." Toen overhandigde Anoc aan Isjtar de ketting van den hemelstier. Zij bracht hem omlaag naar de vlakte van Oerock. Groote verschrikking bracht hij teweeg. Met zijn gesnuif doodde hij honderden menschen. Brieschend valt hij Enkidoe aan. Maar deze ontwijkt zijn aanval en pakt hem bij de horens. Het schuim stond het dier op den bek. Met zijn staart slaat hij Enkidoe neer. Deze roept Gilgamesj: zouden we elkander niet steeds helpen? Gilgamesj geeft aan den oproep gehoor. Weer grijpt Enkidoe den hemelstier, met beide handen grijpt hij hem aan. En Gilgamesj stoot met vaste en kundige hand hem zijn zwaard tusschen 
hoornen en nek. Zij snijden den dooden stier het hart uit en leggen dat voor Sjamasj neer. $Z \mathrm{ij}$ aanbaden den zonnegod en rustten van den strijd.

Daar verschijnt Isjtar op de kanteelen van Oeroeks muur. Ze vervloekt Gilgamesj: „Wee Gilgamesj, die mij beleedigd heeft en den hemelstier gedood!" Enkidoe hoort haar. Hij scheurt de dij van de stier af en werpt die Isjtar naar het hoofd met de woorden: kreeg ik u beet, ik deed $u$ als hem, ik zou u met zijn ingewand behangen!

Toen riep Isjtar haar tempeldienaressen om rouwklacht te houden over de dij van den stier.

Maar Gilgamesj bewonderde met de smeden der stad de geweldige horens van den stier. Hij hing ze op in zijn wapenkamer en bracht een offer aan zijn beschermgod Loegalbanda.

Daarna hielden de helden hun triumphtocht in Oeroek. De menschen stroomden samen om hen te zien en op Gilgamesj' vraag: wie is de geweldigste onder de helden, zongen zijn paleisdames ten antwoord:

Gilgamesj is de grootste onder de helden!

Gilgamesj is de grootste onder de helden!

Enkidoe is de geweldigste onder de mannen!

In zijn paleis vierde Gilgamesj het overwinningsfeest.

\section{DE DOOD VAN ENKIDOE.}

Reeds in den eersten nacht daarop wordt Enkidoe door droomen verschrikt. Hij droomt van een raadsvergadering der goden, waarin Anoe eischt, dat de helden, die Choembaba en den hemelstier gedood hebben, gestraft moeten worden. Hij acht dat Gilgamesj moet sterven, maar Enlil eischt den dood van Enkidoe.. De zonnegod neemt het voor de helden op, maar dit mag niet baten. Enlil spreekt met minachting over Sjamasj' vertrouwelijken omgang met de beide vrienden en handhaaft zijn eisch.

Enkidoe wordt ziek. Gilgamesj zit aan zijn bed en weent hevig omdat de goden nu zijn vriend straffen en hem vrij laten. Hij vreest dat Enkidoe zal sterven en hij hem nooit weer ziet.

In ijlende koortsten doorleeft Enkidoe weer al de gevaren van den tocht naar Choembaba's cederwoud. Hij vervloekt de deerne, die hem uit zijn natuurstaat heeft gelokt. Maar hiertegen komt Sjamasj in verzet en vanuit den hemel zegt hij tot Enkidoe.:

Waarom vervloekt gij de deerne?

Was zij het niet die u brood deed eten en wijn deed drinken, zooals koningen doen?

die u voorname kleeding gaf?

die $u$ deed deelen in Gilgamesj' vriendschap? 
Gilgamesj is nu uw broeder!

Hij laat u rusten op een prachtig bed.

Hij geeft u een eereplaats, links van hem.

Daarom kussen de grooten der aarde uw voeten

en beweenen u de burgers van Oeroek.

En blijft hij na u over-

hij zal zijn lichaam met stof bedekt laten zijn

en gehuld in een leeuwenhuid zwerven door de steppen.

Door deze herinnering van Sjamasj aan de nieuwe positie, waarin hij door de deerne gekomen was, werd Enkidoe een weinig vertroost. Maar een nieuwe vreeselijke droom kwam hem beangstigen. Hij vertelt aan Gilgamesj:

De hemel schreeuwde, de aarde antwoordde!

Vóór mij stond een man met somberen blik.

Hij had een grooten vogelkop,

vleugels als een adelaar en arendsklauwen.

Hij maakte mij weer sterk en gezond,

zette mij op den muur,

liet mij toen diep wegzinken.

Hij veranderde mij van gedaante.

Ik kreeg bevederde armen en leek ook een vogel.

Volg mij, beval hij, naar het huis der duisternis,

waar koningin Irkalla regeert,

naar het huis, waar men wel ingaat, maar niet uitgaat.

Volg mij op den weg zonder terugkeer,

naar het huis welks bewoners het licht derven;

ze zitten in het donker.

Toen ik het stofhuis binnentrad

zag ik koningskronen op den grond liggen.

Koningen, stadhouders van Anoe en Enlil,

dienen vleesch op en brood en koel water.

Daar waren priesters, tooverpriesters en waarzeggers.

Aan koningin Eresjkigal las de schrijfster der onderwereld een

kleitafel voor. Plotseling keek ze op, zag mij aan en nam mij weg . . . .

Jammerend erkent Gilgamesj dat deze droom onheil spelt.

Dagen aaneen ligt Enkidoe op zijn ziekbed. De dood waart rond.

Stervend klaagt Enkidoe:

Roemloos sterf $\mathrm{ik}$, niet in den strijd!

Want eens vreesde ik den strijd!

Mijn vriend, gelukkig is hij, die valt in den strijd!

Ik sterf smadelijk .... 
Bitter heeft Gilgamesj geweend om den dood van zijn vriend: :

O mijn vriend, gij waart mij als een strijdbijl aan mijn heup,

als een boog in mijn hand,

Als een zwaard aan mijn gordel,

als een schild, hoog voor mij opgeheven,

mijn feestkleed, mijn zielsvreugd.

Een booze vijand heeft mij van u weggerukt.

$\mathrm{O}$ mijn vriend, mijn broeder, gij jaagdet den woudezel in de bergen, den panter in de steppe.

Samen beklommen wij de bergen en bereikten ons doel.

We versloegen Choembaba, we doodden den hemelstier.

Wat voor slaap ge nu?

Hooort ge mij niet?

Maar Enkidoe hoorde hem niet. Gilgamesj legde de hand op zijn hart--het klopte niet meer. Gilgamesj schreeuwde het uit van verdriet, hij brulde als een leeuw, die doodelijk is getroffen, als een leeuwin, die van haar jongen beroofd is. Hij trekt zich de haren uit het hoofd, hij werpt zijn kleederen af en laat zich van droefheid ter aarde vallen.

\section{GILGAMESJ OP ZOEK NAAR HET LEVEN.}

Eenzaam zwerft Gilgamesj door de steppe in een leeuwenhuid gehuld en met stof bedekt. Angst jaagt hem voort: hij heeft den dood gezien. Zal hij straks niet zijn als Enkidoe? De angst voor den dood maakt hem onrustig. Hij weet echter: éen mensch is aan het noodlot van den dood ontkomen: Oetnapisjtin, zijn voorvader, de zoon van Oebar Toetoe. Naar hem zal hij gaan, naar de eilanden der zaligen. Den onmogelijken tocht zal hij wagen.

Hij komt bij den Tweelingsberg, de poort waardoor des avonds de zon in de onderwereld daalt. Daar waken schorpioenen. Ze keeren Gilgamesj: „langs dezen weg ging nooit iemand. Het is de nachtelijke zonnebaan, gansch duister. Wat is uw doel?" Gilgamesj zegt dat hij naar zijn voorvader Oetnapisjtin, die eeuwig leeft bij de goden, wil gaan, om hem te vragen over dood en leven. De schorpioenen geven hem nu doorgang en hij betreedt den donkeren weg van West naar Oost, het onderaardsche pad. Mijl na mijl legt hij af in de diepe duisternis. In het Noorden voelt hij den kouden wind. Maar hij reist voort en nog vóór zonsopgang komt hij aan in het uiterste Oosten. Daar ligt de tuin der goden, daar bloeien boomen met edelsteenen.

Daar is de schenkster, Sidoeri, die uit de vruchten van den hof den godendrank bereidt. Daar is de kust van het groote water, van den oceaan. 
Daar komt Gilgamesj gehuld in een leeuwenhuid en met stof bedekt, hij die voor twee derde god was doch onrustg was door doodsangst. Hij is vermoeid van den tocht. Onrustig is zijn gelaat. Als Sidoeri hem ziet houdt ze hem voor een moordenaar, die ver voor zijn vervolgers vlucht Ze grendelt haar deur. Maar Gilgamesj dreigt, dat hij de deur zal inslaan. $\mathrm{Hij}$ is het die Choembaba heeft verslagen en die den hemelstier heeft gedood. De schenkster antwoordde hem: als gij dat deedt waarom is dan uw aangezicht zoo bleek en onrustig? Gilgamesj zeide: Doodsangst jaagt mij voort. Mijn vriend is dood, zijn lot bedrukt mij. Straks zal ik zijn als hij. Mijn vriend ligt in het stof. Ik wilde niet, dat hij begraven werd. Ik hoopte, dat hij van mijn rouwgeschrei weer levend werd. lk weende zeven dagen en zeven nachten, tot de maden in zijn neus kropen .... Sinds zoek ik naar het leven. Sidoeri, zal ik den dood kunnen ontkomen?

De schenkster antwoordde hem: Gilgamesj, staak die moeite! Gij zult het leven niet vinden. Toen de goden de menschen schiepen hebben ze hun den dood toebedeeld en zelf het leven gehouden. Maar eet en drink! Maak alle dagen vreugd. Dans en speel dag en nacht. De deernen laten zich gaarne omhelzen en maken $u$ haar genieting deelachtig.

Met dit middel echter kan Gilgamesj zijn onrust en angst niet verdrijven. Niet de wulpsche Isjtar, maar Sjamasj, de zonnegod, is zijn leidsman.

Aan de overzijde van het groote water verblijft Oetnapisjtin. Maar daarvóór zijn de wateren des doods. Sidoeri wijst hem Oersjanabi, die voor Oetnapisjtin planten zoekt en raadt hem met dien veerman van Oetnapisjtin den tocht te wagen. Oersjanabi draagt hem op honderd en twintig boomen te kappen en daar groote puntstokken van te maken, zestig el lang. Hij kan elke puntstok slechts éénmaal gebruiken, want als zijn hand nat wordt van de wateren des doods zal hij sterven. Als de honderd en twintig puntstokken zijn verbruikt maakt Gilgamesj van zijn kleeding een zeil. Zoo ziet Oetnapisjtin met groote verbazing de boot met den vreemdeling naderen.

Gilgamesj staat voor Oetnapisjtin en deze vraagt hem: waarom is uw aangezicht bleek? waarom ziet gij vermoeid en troosteloos? waarom is er onrust in uw hart? Gilgamesj antwoordt: hoe zou ik niet bleek en vermoeid zijn en onrustig van hart? Mijn vriend is dood! Mijn vriend, mijn broeder, die de woudezels joeg in de bergen en de panters in de steppe. Met hem samen versloeg ik Choembaba en doodde ik den hemelstier. Enkidoe, mijn vriend, dien ik zoo zeer liefhad, die met mij alle gevaren trotseerde.... hij is dood! En straks zal ik zijn als hij! 
Angst en onrust jagen mij voort. Met stof ben ik bedekt. Een leeuwenhuid bedekt mijn leden.

Oetnapisjttin, die het leven vond en bij de goden leeft, antwoordde Gilgamesj: de grimmige dood is onverbiddelijk. Wij bouwen geen huizen voor altijd en gaan niet altijd door met koopen en erfenis deelen en haten. Zal een rivier altoos door stijgen? Niets is er, dat beklijft. Een doode is als een die slaapt. Als een mensch ten doode nadert komen de goden bijeen en de noodlotsgodin, Mammeetoe, bestemt zijn lot. De goden deelen dood en leven uit en de ure des doods blijft onbekend. Maar met deze beschouwing van den eenige, die zelf het leven vond, kan Gilgamesj niet tevreden zijn en hij zegt tot hem: Oetnapisjtin, gij zijt niet anders dan ik! Vertel mij, hoe vond gij het leven?

\section{HET ZONDVLOEDVERHAAL.}

Oetnapisjtin zeide tot Gilgamesj: Ik zal $u$ het geheim vertellen. Ge kent Sjoerippak, de oude stad aan den oever van de Euphraat. Daar besloten de goden tot een grooten watervloed, Anoe de vader der goden en de onvriendelijke Enlil, Ninoerta en Ennoegi; ook Ea was bij hen. Deze nu mocht den raad der goden niet openbaar maken. Maar hij sprak tot mijn riethut en ik begreep: ik moest een schip bouwen en om het leven te behouden achterlaten al mij rijkdom en goed. Ik moest bouwen een schip vierkant van vorm, de lengte gelijk aan de breedte. Ik zeide tot Ea: uw gebod zal ik doen. Maar als de menschen mij vragen wat maakt gij? Ea antwoordde: zeg: Enlil heeft een hekel aan mij. Daarom kan ik hier niet langer wonen. Ik ga naar de diepte waar Ea woont. Dan zal Enlil u rijkelijk beregenen en uw land zal zwemmen van rijkdom!

Ik bouwde het schip. Zijn grondvlak was een bunder groot. Zijn dak zoo hoog als de breedte. Ik maakte zes verdiepingen en deelde het grondvlak in negenen. Ik smolt pek en teer. Voor de werklieden slachtte ik runderen en schapen, bier en wijn deed ik voor hen stroomen als een rivier, zoodat ze genoten als op cen nieuwjaarsdag. Op den zevenden dag was het schip gereed. Ik laadde het vol met mijn goud en zilver. Mijn familie en verwanten deed ik aan boord komen, ook vee en al het gedierte des velds. Toen kwam het teeken, dat Sjamasj gesteld had: als des avonds de wolken samenpakken en de stortregen valt, ga dan in uw schip en sluit het luik. Ik ging in het schip en gaf de leiding aan Poesoer-Amoerri, mijn stuurman. Den morgen daarop stegen zwarte wolken op. Hadads donder dreunde. Zijn herauten trokken voor hem uit over de vlakte. Ninoerta liet de krachten der natuur los. De aarde werd duister. De goden der onderwereld zwaaiden hun toortsen. Het wijde land brak als een aarden schaal. Den ganschen dag waaide de 
Zuidstorm en zette de bergen onder water. De menschen konden elkaar niet zien. Ook de goden werden bang. Ze konden vanuit den hemel geen mensch meer zien. Ze vluchtten omhoog naar Anoe en kropen als honden in een hoek. Isjtar schreeuwde als in barensnood: hoe kon $\mathrm{lk}$ in den raad der goden met zulk een vreeselijk besluit instemmen! Allen komen ze om-de menschen, wien ik het leven schonk! Als visschen vullen ze de wateren! Zes dagen en zeven nachten aaneen wierp de orkaan zich over het land. Toen werd het stil. . De vloed was over. Ik opende het luik en keek uit: rondom stilte! Het menschdom was vergaan. Dicht geslibd was de aarde. Ik ging op den grond zitten weenen om zulk een aanblik.

Het schip dreef in de richting van den berg Nisir. Na zeven dagen liet ik een duif uit, maar ze vond geen plaats om te vertoeven en keerde terug. Toen liet ik een zwaluw uit. . Ook deze vond geen plaats om te vertoeven en keerde terug. Toen liet ik een raaf uit.. Die zag, dat de aarde droog werd, hij vond voedsel en krabde in den grond. Hij keerde niet terug. Toen liet ik allen uit het schip gaan en bracht een offer.

De goden roken den geur van mijn offer en kwamen er als vliegen op af. Maar Isjtar zeide: zoo $\mathrm{min}$ als ik mijn halssieraad vergeet, zoomin vergeet $\mathrm{ik}$ ooit dezen dag. De goden mogen komen tot het offer, maar Enlil niet. Hij heeft dezen vloed teweeggebracht, hij liet mijn menschheid verdrinken.

Toen Enlil kwam en het schip zag werd hij kwaad en vroeg of er menschen ontkomen waren. Want niet één had mogen ontkomen aan den vloed! De goden antwoordden hem: van Ea kan men immers alles verwachten! Toen stond Ea op en sprak tot Enlil: :held, verstandigste onder de goden, hoe ondoordacht deed gij den stortvloed komen. Had toch liever de zondaar gestraft. Had een leeuw gestuurd of een wolf of honger of pest om de menschen te straffen. Dat was beter geweest dan met den vloed allen te verdelgen. Ik echter heb den raad der goden niet openbaar gemaakt. Oetnapisjtin begreep het uit een droom. Maar wat zult gij goden nu met hem doen? Toen ging Enlil naar het schip. Hij vatte mij bij de hand en liet mijn vrouw naast mij knielen. Hij stond tusschen ons in, raakte ons voorhoofd zegenend aan en zeide: Vroeger was Oetnapisjtin een mensch. Van nu af aan zullen hij en zijn vrouw ons, goden, gelijk zijn. Hun woning zal zijn ver weg bij de riviermonding.

\section{GILGAMESJ VINDT HET LEVEN NIET.}

Na dit verhaal zeide Oetnapisjtin tot Gilgamesj: maar wie zal nu voor $u$ de goden bijeenroepen opdat ook gij het eeuwige leven zoudt ontvangen? Maar welaan, wie den dood wil ontgaan, moet minstens den 
slaap weerstand kunnen bieden. Slaap niet zes dayen en zeven nachten. Nauwelijks echter was Gilgamesj gaan zitten of de slaap overviel hem. Toen zeide Oetnapisjtin tot zijn vrouw: deze wil eeuwig leven, maar zelfs de slaap overmant hem. De vrouw sprak tot Oetnapisjtin: maak hem wakker opdat hij huiswaarts ga! Maar Oetnapisjtin zeide: een mensch is boos. Overtuig hem. Bak elken dag een brood. Leg die brooden op zijn hoofd. Het vorige zal droog zijn als het volgende neergelegd wordt. Toen hij het zevende brood neerlegde raakte hij hem aan en Gilgamesj ontwaakte. Toen zei deze: nauwelijks slaap ik of gij stoort mij! Maar Oetnapisjtin zeide: man, tel uw brooden! Zie aan het getal uwer brooden hoeveel dagen gij geslapen hebt! Moedeloos wordt Gilgamesj als hij zijn zwakte bemerkt. Meer dan ooit gevoelt hij, dat hij tegen den dood niet is opgewassen. Hij klaagt: de dood loert in mijn slaapvertrek. Waar ik den voet ook zet, daar grijnst de dood.

Niets rest Gilgamesj dan terug te keeren. Hij lijkt verder van zijn doel dan ooit. . Toch komt hij het nader! Oetnapisjtin raadt hem te baden in het meer op het eiland. Dat zal zijn krachten vernieuwen en zijn kleederen zullen nieuw blijven op de lange reis naar Oeroek.

Gilgamesj en Oersjanabi klimmen in de boot.

Dan zegt Oetnapisjtins vrouw tot hem: een moeizamen tocht heeft deze held gehad. Hij heeft zich afgetobd en ingespannen. Wat geeft gij hem nu hij huiswaarts keert?

Gilgamesj keert naar den oever terug en Oetnapisjtin zegt tot hem: een moeizamen tocht hebt gij gehad. Ge hebt $u$ afgetobd en ingespannen: Wat zal ik u geven op uw weg naar huis? Ik zal u een geheim openbaren: op den bodem van het meer groeit het levenskruid, welks vrucht den grijsaard ween jong maakt. Zoek het. Het heeft doornen als een roos. Keer met die plant naar Oeroek terug.

Gilgamesj bindt steenen aan zijn voeten. Die trekken hem naar de diepte omlaag. Daar vond hij het kruid. Het wondde zijn handen. Maar hij plukte het. Toen deed hij de steenen van zijn voeten, zoodat de stroom hem weer omhoogstuwde. Tot Oersjanabi sprak hij: Dit is het levenskruid. Het geeft den mensch steeds weer zijn krachten terug. Ik breng het naar Oeroek om het daar weer te eten. De naam van de plant is: De Mensch Wordt Als Grijsaard Weer Jong. Ik zal het steeds eten, opdat ik mijn jeugd steeds terug krijg.

Op de terugreis zag Gilgamesj een koele bron en baadde. Een slang rook de geur van het kruid. Stil sloop zij nader en at het op. Toen ze terugsloop vernieuwde haar huid!

Diep verslagen zit Gilgamesj terneer en weenend van teleurstelling zegt hij tot Oersjanabi:: waartoe heb ik mij vermoeid? waartoe mij al dit 
leed getroost? Niets goeds verwierf ik mij. Het is der slang ten goede gekomen!!!

Zonder het leven te hebben gevonden komt Gilgamesj in Oeroek terug. Maar daar zijn zijn onvergankelijke werken( die hij toont aan Oersjanabi: de stadsmuur van Oeroek, de versterkte stad en de tempel van Isjtar, het E-ANNA, het HEMELHUIS.

Een muur als koper zoo vast! Welk een bouwwerk! Zie toch die versterking! Niemand zou het zoo kunnen namaken! Voel dien hoek. steen, hoe hard is hij, sinds overoude tijden gelegd!

Kom nader en zie den tempel, waar Isjtar woont! Geen koning der toekomst zal ooit weer zulk een tempel kunnen bouwen!

Beklim Oeroeks muur! Loop er op! Bezie de fundamenten! Keur het metselwerk! Zijn het geen harde in het vuur gebakken steenen? Is die grondslag niet het werk der zeven wijzen?

J. H. KROEZE.

Potchefstroom. 